\title{
Use of data envelopment analysis to benchmark environmental product declarations-a suggested framework
}

\author{
M. Galindro, Bruno; Bey, Niki; Olsen, Stig Irving; E. Fries, Carlos; R. Soares, Sebastião
}

Published in:

International Journal of Life Cycle Assessment

Link to article, DOI:

10.1007/s11367-019-01639-1

Publication date:

2020

Document Version

Peer reviewed version

Link back to DTU Orbit

Citation (APA):

M. Galindro, B., Bey, N., Olsen, S. I., E. Fries, C., \& R. Soares, S. (2020). Use of data envelopment analysis to benchmark environmental product declarations-a suggested framework. International Journal of Life Cycle Assessment, 25, 2417-2431. https://doi.org/10.1007/s11367-019-01639-1

\section{General rights}

Copyright and moral rights for the publications made accessible in the public portal are retained by the authors and/or other copyright owners and it is a condition of accessing publications that users recognise and abide by the legal requirements associated with these rights.

- Users may download and print one copy of any publication from the public portal for the purpose of private study or research.

- You may not further distribute the material or use it for any profit-making activity or commercial gain

- You may freely distribute the URL identifying the publication in the public portal 


\title{
The International Journal of Life Cycle Assessment https://doi.org/10.1007/s11367-019-01639-1
}

\section{USE OF DATA ENVELOPMENT ANALYSIS TO BENCHMARK ENVIRONMENTAL} PRODUCT DECLARATIONS - A SUGGESTED FRAMEWORK

\author{
*bruno.menezes@ifsc.edu.br \\ ${ }^{1}$ IFSC - Federal Institute of Education, Science and Technology of Santa Catarina, Campus Gaspar, Brasil. \\ ${ }^{2}$ CICLOG - Life Cycle Assessment Research Group, Federal University of Santa Catarina - UFSC - Florianópolis, \\ ${ }^{3}$ Sustainability Division, Department of Technology, Management and Economics, Technical University of \\ Denmark - DTU, Kgs. Lyngby, Denmark \\ ${ }^{4}$ Department of Production Engineering, Federal University of Santa Catarina - UFSC - Florianópolis, Brazil
}

\section{ABSTRACT}

Purpose Environmental Product Declarations (EPDs) are standardized tools based on Life Cycle Assessment (LCA) to communicate and compare environmental performance of products according to well-defined Product Category Rules (PCRs). However, despite the comparability enabled by the PCRs, the use of this information for benchmarking is still challenging, since there is still no consensus or standardization regarding techniques and procedures to be adopted. Therefore, here we suggest and apply a framework to benchmark and develop a ranking system for the products based on data from EPDs.

Methods The proposed framework is based on efficiency assessment using Data Envelopment Analysis (DEA). The main advantages of DEA are that it does not require potentially non-scientific factors, e.g. for normalization and that it provides an efficiency score based on all the used indicators, rather than just based on a subset of them. A five-step benchmarking framework is presented which includes: data collection from EPDs, statistical analyzes, selection of the variables, application of DEA, and cluster analysis to establish the environmental performance ranking on a scale from A (best) to $\mathrm{E}$ (worst). In order to illustrate the applicability of the proposal, two case studies of different product categories are presented: bakery products and insulation materials.

Results and discussion In the first case, 72 bakery products are evaluated of which 9 were ranked in the category A, while 9 other products are considered the most inefficient and were ranked in category E. For insulation materials, 89 products are evaluated and 9 are categorized as A of which 5 are considered efficient, while the category E comprises 20 products. The results obtained through DEA are compared with those from other approaches (being internal normalization and external normalization, respectively, each with subsequent aggregation) to obtain single scores. There are significant differences in the results obtained from the three approaches, especially when dealing with trade-offs, because DEA does not relate the scores to specific values, but to a so-called "efficiency frontier".

Conclusions The use of DEA allows an analysis based on the efficiency of the products in terms of environmental performance and can be applied using data from EPDs. The framework proposed allows 
benchmarking of the results and opens a new perspective to contribute to the issue of limitations in the communication function of EPDs. However, DEA is limited to analyzing the efficiency of a given product in relation to a pre-determined group.

Keywords: Data Envelopment Analysis, benchmarking, comparability, Environmental Product Declarations, Life Cycle Assessment, communication.

Environmental labeling can be defined as a statement that indicates the environmental performance of a product, whether it is a good or a service. The ISO 14020:2000 establishes guidelines for environmental labeling processes, as well as creating and maintaining programs. According to the norm, an environmental claim or statement may appear in the form of a text, a symbol or a graphic element on a product or packaging label, product literature, technical bulletins, advertising or publicity (ISO 2000). ISO 14020 also proposes a classification system for environmental labeling processes, dividing them into three main groups: Type I - Environmental Labels, Type II - Environmental Self-declarations and Type III - Environmental Product Declarations (EPDs). The principles for developing Type III EPDs are standardized in the ISO 14025 (ISO 2006a), which establish that EPDs must present quantitative information on the environmental performance of a specific product, based on the Life Cycle Assessment (LCA) methodology. Ibáñez-Forés et al. (2016) suggest that, opposite to Type I ecolabels, the use of EPDs could prevent the confusion in the communication of the environmental performance of products. EPD programs are currently growing, in terms of the number of programs being implemented worldwide and the number of declarations issued by these initiatives, with 27 programs listed by Hunsager et al. (2014) and 39 in the updated list by Minkov et al. (2015).

According to Fet and Skaar (2006), the so-called Product Category Rules (PCRs) of an EPD program define the information that should be included in the EPDs for a specific product category, in addition to the general program guidelines. One of the essential requirements for obtaining an EPD is that it is based on reliable, consistent and comparable information. The EPDs must be based on LCA studies that are all in accordance with a common standard in terms of methodological decisions, such as the functional unit adopted and the impact assessment methodologies considered. Additionally, PCRs have the objective of facilitating communication regarding the environmental performance of products among stakeholders (Fet and Skaar 2006, Ingwersen and Stevenson 2012, Del Borghi 2013).

However, in practice the comparability across EPDs from different programs is still limited by some issues as the need for harmonization of PCRs (Del Borghi 2013, Hunsager et al. 2014, Minkov et al. 2015, Gelowitz and McArthur 2017) and the use of generic data in the development of analyzes (Modahl et al. 2013). In addition,

72 standards and procedures for benchmarking have not yet been established, although they are encouraged by 73 initiatives such as the European Commission in the development of the Product Environmental Footprint (PEF) 74 (European Commission 2013). In terms of EPDs, benchmarking initiatives are still timidly addressed, such as Gül et 
al. (2015), which proposes a ranking system based on the results of potential global warming impacts. Other attempts for making comparisons across LCA studies, e.g. on the basis of uncertainty analysis, showed to be limited in the outcomes and potentials (Henriksson et al. 2015, Heijungs et al. 2017). In a broader perspective, the application of benchmarking techniques to LCA studies was evaluated by Galindro et al. (2019) and it is noticed that although some initiatives are adopted, there is still no consensus nor norms to develop this practice.

One of the potentially suitable benchmarking techniques to be applied in EPD-information is Data Envelopment Analysis (DEA), that has been used as benchmarking technique combined with LCA results, (see Vázquez-Rowe and Iribarren 2015, Laso et al. 2018, Galindro et al. 2019). The combination of LCA+DEA have been used as an efficiency analysis and benchmarking tool both in product-oriented as in organization-oriented perspectives (Galindro et al. 2019). It was identified the application of this technique in studies which included different production systems, such as: livestock and agricultural crops (Iribarren et al. 2010; 2011, Mohammadi et al. 2013; 2015, Vázquez-Rowe et al. 2012, Beltrán-Esteve et al. 2017), marine crops (Iribarren et al. 2010, Lozano et al. 2009; 2010, Ramos et al. 2014, Vázquez-Rowe et al. 2010; 2011, Avadí et al. 2014), energy production (Iribarren et al. 2013; 2014, Vázquez-Rowe and Iribarren, 2015, Martín-Gamboa et al. 2016, Martín-Gamboa and Iribarren 2016,), water and wastewater treatment systems (Lorenzo-Toja et al. 2015; 2016; 2018), food production (Egilmez et al. 2014; 2016) and construction materials ( $\mathrm{Li}$ et al. 2013, Iribarren et al. 2015).

Therefore, the present study aims to contribute to the development of benchmarking of products based on their EPDs, supported by the comparability ensured by the fact that the EPDs belong to the same PCR. For this, we propose a framework based on DEA and on an environmental performance ranking system. It is intended that the information obtained based on the suggested framework will facilitate the understanding, decision making and communication among stakeholders. Also, it is expected that it can be applied both in the communication between practitioners and in the non-specialist stakeholders.

For this, the present study is organized as follows: Section 2 presents a general view on LCA, DEA and the chosen model, while Section 3 presents and details the suggested framework and the assumptions adopted. In order to illustrate and demonstrate the applicability of the framework, Section 4 presents two case studies, specifically for the product categories of bakery products and insulation materials. Also in this Section, there is a comparison between the results obtained with the proposed framework and other single scores methods (internal normalization or external normalization and aggregation) and a discussion of the results. Finally, Section 5 presents the conclusions and recommendations.

104

\section{LCA AND DEA OVERVIEW}

106

\subsection{Life Cycle Assessment (LCA)}

The core of an EPD is grounded by a LCA of a product system, carried out in accordance with the criteria in the ISO standardization 14025, 14040 and 14044 (ISO 2006a, b, c). Complimentary, but also respecting the ISO 
112 consequently, the methodological four phases of a LCA study (Goal and scope definition; Life Cycle Inventory 113 (LCI) analysis; Life Cycle Impact Assessment (LCIA); and Interpretation) should be covered prior to (or to reach) 114 the publication of an EPD publication. In addition, the specific standards for each product category defined in the 115 corresponding PCR should be followed. This means that the objective and scope must be outlined, the LCI must be reported, the LCIA methodology must be declared and the results must be discussed in the interpretation phase.

\subsection{Data Envelopment Analysis (DEA)}

DEA is a non-parametric estimation technique of relative efficiency of productive units, known as Decision Making Units (DMUs), that can represent companies of a particular economic sector, products or services with common characteristics (like products relating to a PCR), for example. The main objective of the DEA is to identify and classify the performance/efficiency of the DMUs regarding their capability of converting inputs to outputs (Cooper et al. 2007, Cylus et al. 2017). For this, a linear programming methodology proposed by Charnes, Cooper and Rhodes (1978) is used, with which DEA formulates and solves an optimization model that produces an efficiency score and a target operating point for each of the DMUs (Lozano et al. 2009; Vázquez-Rowe et al. 2010). Thus, DEA defines the efficiency curve, considering the optimal relation between inputs and outputs and the DMUs that maximize this relation, the so called "efficient" or "best-in-class". In turn, the inefficient units are positioned below the curve, "enveloped" by the performance of the efficient units (Fries 2013, Zhu 2015). Thereby, the operational efficiency reference values established serve as the basis for the benchmarking practice, basically seeking to decrease the magnitude of inputs for each unit of output produced, which would result in improved efficiency (Vázquez-Rowe et al. 2010).

The efficiency analysis through DEA varies according to two main characteristics: the properties of returns to production scale and the orientation of the model (Fries 2013). Returns to scale refer to the production response to the change in the quantity of productive inputs, which can result in constant or variable returns regarding the outputs. Constant Returns to Scale (CRS) occurs when variations in the quantities of inputs cause proportional variations in the products - here represented by the outputs, assuming that the units operate at an optimum scale, with a maximized use of the inputs. On the other hand, in the situation of Variable Returns to Scale (VRS), the variations in the quantities of inputs cause non-proportional returns in the products, being able to assume increasing, decreasing, non-increasing or constant returns (Cooper et al. 2007, Zhu 2015). Regarding the orientation of the model, productive efficiency can be analyzed from the point of view of inputs or outputs. The orientation to inputs seeks to minimize the consumption of inputs to obtain a certain quantity of products, while the orientation to outputs considers efficient the units that obtain the largest quantity of products considering the same quantity of inputs.

\subsection{LCA + DEA Application}

Different application formats of DEA integrated with LCA results data can be found in the literature, such as CRS, VRS, 3-step, 5-step, for example (see Galindro et al. 2019). Specifically for this proposal, the BCC model, 
suggested by Banker, Charnes and Copper, that distinguishes between technical and scale inefficiencies, highlighting the efficiencies obtained through the VRS model (Cooper et al. 2007, Fries 2013, Zhu 2015) is chosen, in order to guarantee a greater detailing of the results. Avadí et al. (2014) affirm that suggesting that DMUs operate efficiently from a CRS perspective may have hidden inefficiencies that are only visible if a VRS is applied to the systems evaluated. Likewise, the input-oriented model was selected because it is the one that best applies to the data available in the EPDs. In this case, DEA is used to understand who is capable of producing a certain quantity of outputs (represented by the functional/declared unit), generating a smaller amount of inputs (the environmental impacts, here represented by the LCIA indicators). This approach is recommended by Seiford and Zhu (2002) when using environmental impact data in the analysis, referred to as "undesired inputs".

According to Fries (2013), the mathematical concept of the BCC input-oriented model can be presented as follows: "For a given DMU or a set of $n$ production units with $r$ inputs $\mathrm{X}$ and $s$ outputs $\mathrm{Y}$, the goal is to determine the set of weights $v_{i},(i=1, \ldots, r)$, and $u_{j},(j=1, \ldots, s)$, which maximizes the relation between its weighted outputs and inputs, subject to the restriction that for each DMU of the set to be analyzed, the weighted sum of its outputs is limited by the weighted sum of its inputs".

Regarding the formulation, the input-oriented $\mathrm{BCC}$ model can be represented according to Equation 1 (Cooper et al. 2007):

$\operatorname{maximize}(u, v) e_{o}=\sum_{j=1}^{s} u_{j} Y_{j o}-u_{m}$

Subject to:

$$
\begin{array}{lr}
\sum_{j=1}^{s} u_{j} Y_{j m} \leq \sum_{i=1}^{r} v_{i} X_{i m}+u_{m} & m=l, \ldots, n \\
v_{i} \geq 0 & i=l, \ldots, r \\
u_{j} \geq 0 & j=l, \ldots, s
\end{array}
$$

$u_{m} \in \mathbb{R}$

$X=$ inputs; $Y=$ outputs; $u, v=$ weights

Where $Y_{j m}$ and $X_{i m}$ are the inputs and outputs of the $m$-th DMU, $u_{j}$ and $v_{i}$ represent the weights to be determined by the solution of the problem. This process is repeated for each of the DMUs, obtaining different values for $\mathrm{u}_{\mathrm{j}}$ and $\mathrm{v}_{\mathrm{i}}$. The model seeks to minimize the consumption of inputs $\mathrm{Y}$ in order to produce a given level of production, represented by the maximization of the sum of the outputs Y multiplied by the weights $u$.

In the first restriction, the sum of the products of the inputs by the weights for a given $\mathrm{DMU}_{\mathrm{o}} \sum_{i=l}^{r} v_{i} X_{i o}$ is equal to 1 , which means that the maximum possible value to be obtained is 1 . Thus, it can be stated that the DMUs with $\mathrm{e}_{\mathrm{m}}=1$ are operating at the efficiency frontier, while those with $\mathrm{e}_{\mathrm{m}}<1$ are operating outside this frontier and are considered inefficient when compared to the first ones (Cooper et al. 2007, Fries 2013). In turn, the second restriction $\left(\sum_{j=1}^{S} u_{j} Y_{j m}\right)$ refers to the limitation of the sum of the product of the outputs by the weights in a maximum value less than or equal to that obtained by the sum of the product of the inputs by their respective 
weights $\left(\sum_{i=1}^{r} v_{i} X_{i m}\right)$, since it is considered that the maximum efficiency is reached when all inputs are converted into outputs. The introduction of variable $u_{m}$ represents the variable returns of scale and refers to the scaling efficiency quotient referring to the projection of the distances of the real DMUs in relation to the target DMUs. An example of the operation of the input-oriented DEA VRS model can be seen in Fig 1.

In the example shown in Figure 1, two variable inputs are considered for a given constant output, e.g., the functional unit. The solid line represents the efficiency boundary formed by the efficient DMUs (black bullets - A, $\mathrm{C}, \mathrm{D}$ and F). In turn, the inefficient DMUs are represented by red bullets (B and E) and their efficiency projections are marked by dashed lines. Thus, the green bullets (B' and E') represent the target input values required for these DMUs to be considered efficient.

\section{Input 1}

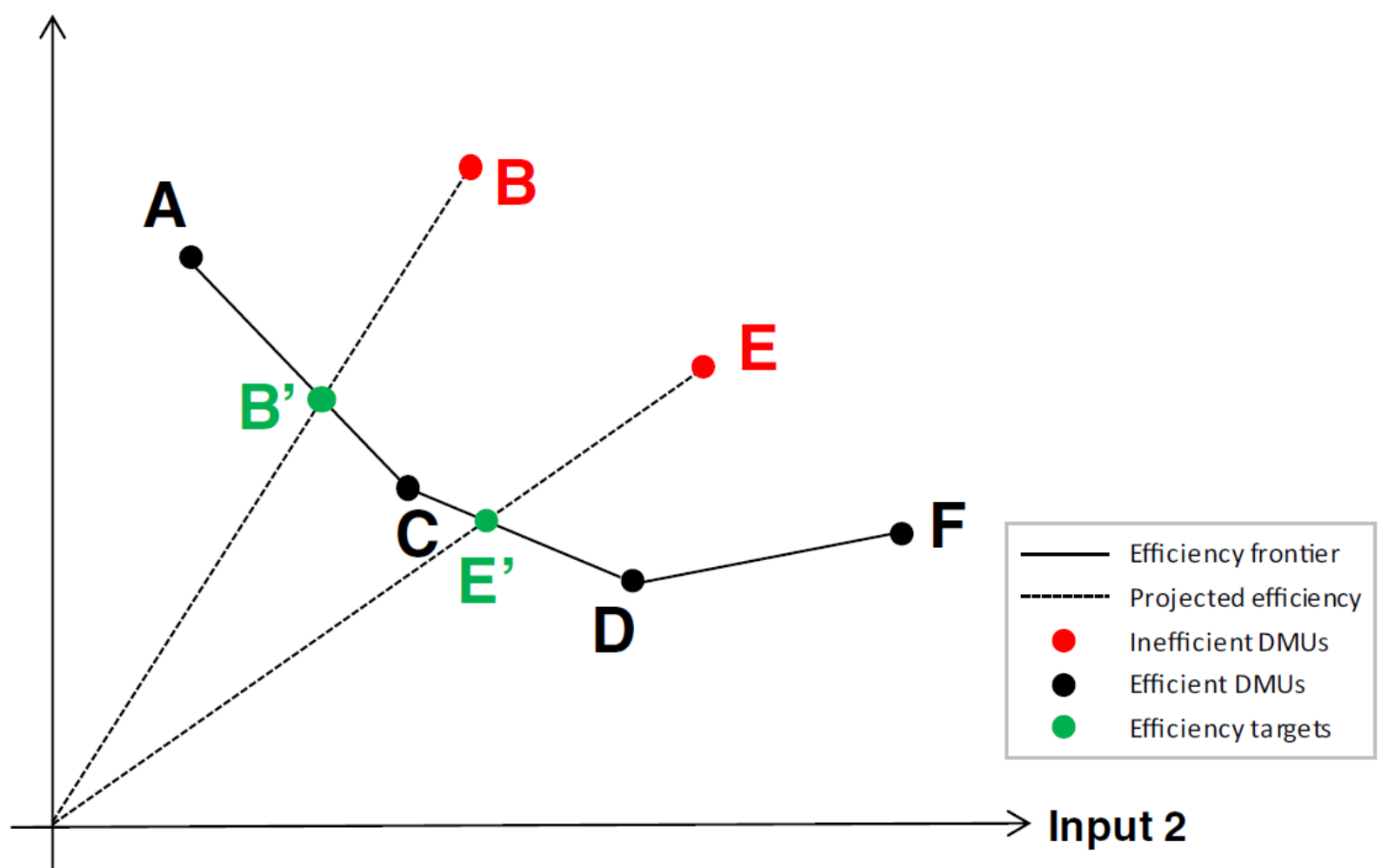

Fig. 1: Example of the DEA BCC input-oriented model application, considering two inputs and one constant output

\section{DEVELOPMENT OF THE BENCHMARKING FRAMEWORK}

In this section, the framework of the proposed environmental performance benchmarking system and the application in the case studies are presented. 


\subsection{Suggested framework}

Based on recommendations from Galindro et al. (2018) to use statistical analyzes to reduce the dimensionality of the indicators, to use DEA to assess the efficiency and to establish a ranking system based on the results, a 5-step approach is proposed. The justifications of the methodological choices, as well as the detail of the procedures adopted in each step, are presented in items 1 to 5 .

1. Data collection from EPDs: In order to increase the comparability of the data, the following data selection criteria are adopted:

- data is collected from EPDs built under the same PCR, including the specific version;

- only EPDs that have the same functional/declared unit must be used in order to ensure comparability;

- only the data referring to the LCIA indicators were selected, since the lists of LCI indicators are not consistent even between products of the same category;

- only the results of the evaluation of modules A1 to A3, which refers to the upstream and core processes, or a "cradle-to-gate" life cycle are considered (A1 is raw material supply stage, A2 is the transport of the raw material stage and A3 is the manufacturing stage). The choice of these modules is because the considerations used in the following stages may vary between the different declarations i.e., the delivery location of the product in the transport stage.

2. Statistical analyzes: Limleamthong et al. (2016) affirm that DEA is very sensitive regarding the number of variables considered in the analysis. In fact, Cooper et al. (2007) state that the number of inputs adopted should be enough to discriminate efficient DMUs, but not to deem many units as efficient, which could lead to a poor analysis. That is particularly observed when variables are highly correlated and can be avoided by performing linear correlation analysis and Principal Component Analysis (PCA). Thus, the correlated variables can be identified and, if necessary, its importance in the formation of the data components can be clarified.

3. Selection of variables: the LCIA indicators selected are those not strongly correlated (correlation less than 0,9). If a strong correlation is identified, it is recommended to select the variable that presents the highest eigenvalue, according to the PCA results.

4. Application of DEA: As previously mentioned, the DEA model selected for use in this system is the BCC with Variable Returns of Scale (VRS), since this approach guarantees a greater detailing for the results (Avadí et al. 2014). The input-oriented model is also adopted, once the functional/declared unit is considered the single output of this system. In this way, it is sought to identify which DMUs are capable of producing the same quantity of product - here represented by the functional/declared unit - generating the least amount of undesirable inputs (Seiford and Zhu 2002), that is, causing less environmental impact, concerning the LCIA indicators. The outcomes of this analysis are values ranging from close to 0 to 1 , with 1 being attributed the efficient DMUs and values close to 0 indicating the least efficient. It is worth mentioning that DEA constitutes an evaluation of relative efficiency among the DMUs analyzed (Cooper et al. 2007), thus not presenting an absolute efficiency index (Iribarren et al. 2015). The inclusion of a new DMU to the analysis can establish a new panorama of efficiency for the others 
239 (Limleamthong et al. 2016). As for the application of DEA, many different tools and software are available 240 depending on the demands and specificities of each situation (see Paradi et al. 2018). Specifically, in this study the 241 online software Gurobi Optimizer Gams (Gropp and Moré 1997) was used because it is able to run the selected 242 model.

243 Regarding the weighting, it is considered that all the indicators used in the analysis have the same weight,

244 that is, equal to 1 since the focus of the paper is on demonstrating the applicability of the framework. DEA 245 establishes itself a sum of weights for each inefficient DMU based on its projection in the efficiency frontier, e.g., if 246 the result of the DEA is 0,8 for a given DMU, it means that overall the inputs should be reduced to 0,8 of the current 247 values so this DMU can be considered efficient. However, it is important to note that DEA allows the use of 248 different sets of weights for the variables, either by criteria defined by the decision maker or by a set of preestablished weights (Cooper et al. 2007, Limleamthong et al. 2016).

5. Cluster analysis: Through the efficiency results generated by the DEA, a cluster analysis is performed, in which it is possible to group the DMUs according to their environmental performance. In this case, the standard of 5 252 clusters is adopted according to the orientation of the European Union regarding the benchmarking of the results of 253 PEF (European Commission 2013). Once the number is predefined, K-means clustering is applied, and the members 254 of each cluster are defined based on the distance of cluster members to the center. There is no predetermined size of 255 the clusters, and they do not need to have the same number of DMUs. In addition, a color scale and a letter system 256 (A - best to E - worst) are used to name the groups, also based on guidelines for PEF (BIO Intelligence Service 257 2012), as can be seen in Fig. 2.

258 Fig. 2 presents an overview of the framework and the steps involved. 


\section{Data collection from EPDs}

LCIA Indicators Modules A1 to A3

\section{Statistical analyzes}

Linear correlations

Principal Component

Analysis (if necessary)

\section{Selection of variables}

Non correlated Greater eingenvalues

\section{Application of Data Envelopment Analysis}

Variable Returns of Scale (VRS) Input-oriented

Inputs: LCIA indicators
Output: functional/declared unit Efficiency results: from 1 (efficient) to close to 0 (decreasing efficiency)

\section{Cluster analysis}

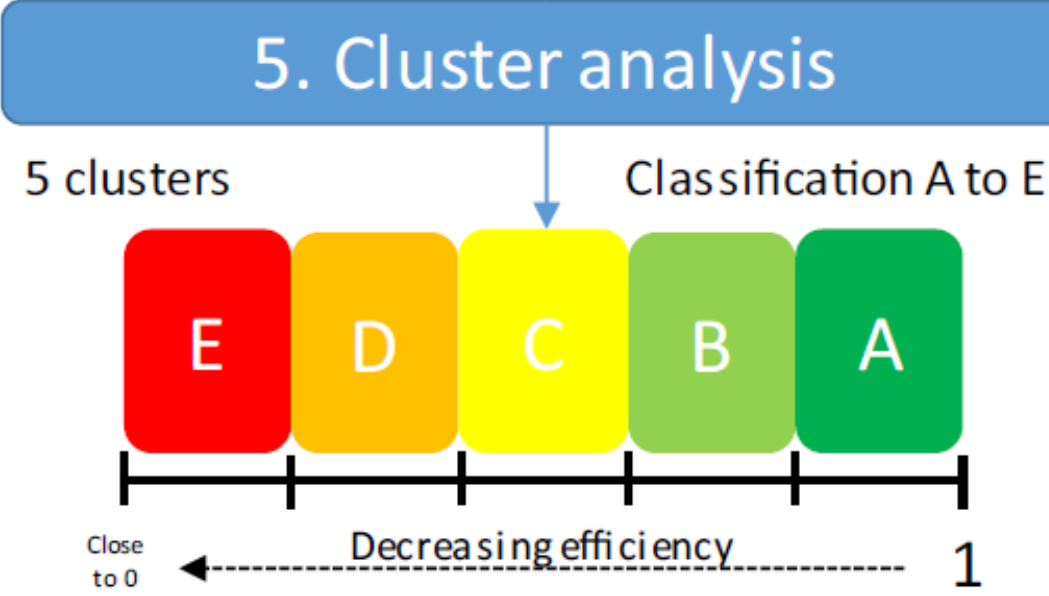

Fig. 2: Framework of the benchmarking and performance ranking system using data from EPDs proposed in this study

\subsection{Application in case studies}

In order to verify the practical application of the suggested framework, two case studies were conducted with data from published EPDs. As a source of information, the database of The International EPD System was 
used, which is the program with the highest number of EPDs and PCRs published (Minkov et al. 2015). The categories of bakery products and insulation materials, which have the highest number of published EPDs for the same PCR within this program (72 and 89, respectively), were selected for study and only the LCIA data published in the EPDs of both categories of products were considered for analysis, following the suggested framework, although this may omit some relevant categories. In both cases, the LCIAs performed to obtain the EPDs followed the CML-IA method (Oers 2015), according to the program recommendation, although the impact categories evaluated were not the same (see items 4.1 and 4.2). The LCIA method and the categories to be evaluated are chosen by the performers of the LCA and the respective EPD, according to the recommendations contained in the specific PCRs and in agreement with the program operator. For bakery products, the EPDs are built according to the PCR 2012:06 version 2.0 (Environdec 2012), while for insulation materials the PCR 2014:13 version 1.0 (Environdec 2014) is followed. To identify the products, a code was adopted that includes the acronym "BP" for bakery products or "IM" for insulation materials, each followed by a number.

\section{RESULTS AND DISCUSSION}

The results based on the proposed methodology are presented in the two practical applications: bakery products and insulation materials. The detail of each of the case studies will be discussed below.

\subsection{Case study: bakery products}

In the information collected on the 72 products the results are presented according to the declared unit " 1 $\mathrm{kg}$ of product and the related packaging for the selling units" and include bread, cakes, cookies and crackers, for example. Based on the PCR recommendations, the LCIA results are presented in four characterized impact categories:

- Global Warming Potential - fossil contribution (GWP), in $\mathrm{kg} \mathrm{CO}_{2}$ equivalent;

- Acidification Potential (AP), in $\mathrm{g} \mathrm{SO}_{2}$ equivalent;

- Eutrophication Potential (EP), in $\mathrm{g} \mathrm{PO}_{4}^{-}$equivalent;

- Photochemical Ozone Creation Potentials (POCP), in $\mathrm{g}_{2} \mathrm{H}_{4}$ equivalent.

Statistical analyzes show that there is no high correlation (values above 0,9) between the 4 categories analyzed, which means that all can be used as inputs in the DEA (Table 1). 
Table 1: linear correlations between the impact category values from the EPDs of the insulation materials

306 and bakery products analyzed.

\begin{tabular}{|c|c|c|c|c|c|c|c|c|c|c|}
\hline \multicolumn{7}{|c|}{ Insulation materials } & \multicolumn{4}{|c|}{ Bakery products } \\
\hline & GWP & ODP & $\mathbf{A P}$ & EP & POCP & ADPE & & GWP & AP & EP \\
\hline ODP & 0,53 & & & & & & $\mathbf{A P}$ & 0,85 & & \\
\hline $\mathbf{A P}$ & 0,68 & 0,77 & & & & & EP & 0,78 & 0,86 & \\
\hline EP & 0,57 & 0,41 & 0,66 & & & & POCP & 0,57 & 0,22 & 0,15 \\
\hline POCP & 0,75 & 0,42 & 0,43 & 0,34 & & & & & & \\
\hline ADPE & 0,48 & 0,21 & 0,11 & 0,33 & 0,54 & & & & & \\
\hline ADPF & 0,88 & 0,39 & 0,70 & 0,76 & 0,64 & 0,32 & & & & \\
\hline
\end{tabular}

The values of the impact categories evaluated (modules A1-A3) are presented in Table 2. The table also presents the results of the DEA application and the proposed classification from the cluster analysis of the resulting efficiency values established via DEA. For example, BP1 has a GWP of 12,04 $\mathrm{kg} \mathrm{CO}_{2}$ eq, AP of 8,95 $\mathrm{g} \mathrm{SO}_{2}$ eq, EP of 5,30 $\mathrm{g} \mathrm{PO}_{4}^{-}$eq and a POCP of $0,80 \mathrm{~g} \mathrm{C}_{2} \mathrm{H}_{4}$ eq, leading to the DEA value of 0,53 . Then, BP1 is clustered in the ranking $\mathrm{B}$ of the products analyzed.

Table 2: Indicators of LCIA (GWP, AP, EP and POCP), DEA and classification (letter and coloring), considering modules A1-A3 of EPDs of bakery products.

\begin{tabular}{|c|c|c|c|c|c|c|}
\hline & $\begin{array}{c}\text { GWP } \\
\left(\mathrm{kg} \mathrm{CO}_{2} \mathrm{eq}\right)\end{array}$ & $\begin{array}{c}\mathbf{A P} \\
\left(\mathrm{g} \mathrm{SO}_{2} \mathbf{e q}\right)\end{array}$ & $\begin{array}{c}\mathbf{E P} \\
\left(\mathrm{g} \mathrm{PO}_{4}^{-} \mathrm{eq}\right)\end{array}$ & $\begin{array}{c}\text { POCP } \\
\left(\mathrm{g} \mathrm{C}_{2} \mathrm{H}_{4} \text { eq }\right)\end{array}$ & DEA & CLASS \\
\hline BP01 & 1,204 & 8,95 & 5,30 & 0,80 & $\mathbf{0 , 5 3}$ & B \\
\hline ВP02 & 1,154 & 7,91 & 5,01 & 0,79 & $\mathbf{0 , 5 6}$ & B \\
\hline ВP03 & 0,661 & 7,42 & 4,38 & 0,09 & 0,78 & A \\
\hline ВP04 & 0,594 & 5,73 & 3,87 & 0,09 & 0,78 & A \\
\hline BP05 & 0,587 & 5,90 & 4,04 & 0,09 & 0,78 & A \\
\hline ВР06 & 1,625 & 16,43 & 9,27 & 0,33 & $\mathbf{0 , 3 0}$ & D \\
\hline ВP07 & 0,636 & 6,07 & 4,22 & 0,14 & $\mathbf{0 , 6 7}$ & B \\
\hline ВР08 & 1,309 & 10,50 & 8,16 & 0,24 & $\mathbf{0 , 3 5}$ & D \\
\hline ВР09 & 1,644 & 12,90 & 9,31 & 0,34 & $\mathbf{0 , 3 0}$ & D \\
\hline BP10 & 1,285 & 10,05 & 7,33 & 0,22 & $\mathbf{0 , 3 9}$ & $\mathrm{C}$ \\
\hline BP11 & 1,279 & 9,79 & 7,19 & 0,22 & $\mathbf{0 , 3 9}$ & $\mathrm{C}$ \\
\hline BP12 & 1,493 & 11,77 & 8,45 & 0,30 & $\mathbf{0 , 3 3}$ & D \\
\hline BP13 & 1,369 & 11,21 & 7,71 & 0,63 & $\mathbf{0 , 3 7}$ & $\mathrm{C}$ \\
\hline BP14 & 0,838 & 6,50 & 4,31 & 0,13 & 0,65 & B \\
\hline BP15 & 0,667 & 6,60 & 4,28 & 0,13 & 0,66 & B \\
\hline BP16 & 0,913 & 8,76 & 6,33 & 0,13 & 0,54 & B \\
\hline BP17 & 0,748 & 5,97 & 4,73 & 0,13 & $\mathbf{0 , 6 0}$ & B \\
\hline BP18 & 1,098 & 3,57 & 5,03 & 0,92 & $\mathbf{0 , 8 4}$ & A \\
\hline BP19 & 1,091 & 3,54 & 4,98 & 0,91 & $\mathbf{0 , 8 5}$ & A \\
\hline BP20 & 2,594 & 23,07 & 15,06 & 0,63 & $\mathbf{0 , 1 9}$ & E \\
\hline BP21 & 1,421 & 12,01 & 7,11 & 0,72 & 0,40 & $\mathrm{C}$ \\
\hline BP22 & 2,468 & 21,01 & 13,13 & 0,58 & $\mathbf{0 , 2 2}$ & $\mathrm{E}$ \\
\hline BP23 & 1,564 & 14,18 & 11,56 & 0,37 & 0,26 & D \\
\hline BP24 & 1,705 & 10,79 & 7,90 & 0,75 & $\mathbf{0 , 3 6}$ & $\mathrm{C}$ \\
\hline BP25 & 2,498 & 16,64 & 8,70 & 0,71 & $\mathbf{0 , 3 2}$ & D \\
\hline BP26 & 2,267 & 18,17 & 10,49 & 0,74 & $\mathbf{0 , 2 7}$ & D \\
\hline BP27 & 2,498 & 16,64 & 8,70 & 0,71 & $\mathbf{0 , 3 2}$ & D \\
\hline BP28 & 2,504 & 21,34 & 12,17 & 0,72 & $\mathbf{0 , 2 3}$ & $E$ \\
\hline BP29 & 2,209 & 17,07 & 10,59 & 0,82 & $\mathbf{0 , 2 7}$ & D \\
\hline
\end{tabular}




\begin{tabular}{|c|c|c|c|c|c|c|}
\hline BP30 & 1,475 & 10,35 & 6,39 & 0,28 & 0,44 & $\mathrm{C}$ \\
\hline BP31 & 1,869 & 13,27 & 10,45 & 0,40 & 0,27 & D \\
\hline BP32 & 1,897 & 10,74 & 7,31 & 1,29 & $\mathbf{0 , 3 9}$ & C \\
\hline BP33 & 2,009 & 11,84 & 7,79 & 1,39 & 0,36 & $\mathrm{C}$ \\
\hline BP34 & 1,997 & 9,28 & 5,31 & 1,07 & $\mathbf{0 , 5 3}$ & B \\
\hline BP35 & 1,430 & 10,59 & 11,49 & 0,27 & 0,29 & D \\
\hline BP36 & 1,786 & 13,13 & 10,35 & 0,38 & 0,27 & D \\
\hline BP37 & 1,392 & 10,53 & 10,95 & 0,25 & $\mathbf{0 , 3 0}$ & D \\
\hline BP38 & 1,498 & 10,44 & 6,47 & 0,72 & 0,44 & $\mathrm{C}$ \\
\hline BP39 & 1,506 & 10,32 & 6,34 & 0,77 & 0,45 & $\mathrm{C}$ \\
\hline BP40 & 2,171 & 18,47 & 14,86 & 0,46 & $\mathbf{0 , 1 9}$ & $E$ \\
\hline BP41 & 1,691 & 11,92 & 9,39 & 0,32 & $\mathbf{0 , 3 0}$ & D \\
\hline BP42 & 1,297 & 7,11 & 5,98 & 0,73 & 0,47 & $\mathrm{C}$ \\
\hline BP43 & 1,044 & 7,36 & 4,81 & 0,07 & $\mathbf{1 , 0 0}$ & A \\
\hline BP44 & 0,975 & 7,04 & 5,15 & 0,07 & $\mathbf{1 , 0 0}$ & $\mathrm{A}$ \\
\hline BP45 & 0,813 & 6,78 & 4,39 & 0,33 & 0,64 & B \\
\hline BP46 & 1,213 & 12,75 & 6,79 & 0,35 & 0,42 & $\mathrm{C}$ \\
\hline BP47 & 2,062 & 17,52 & 9,31 & 0,84 & $\mathbf{0 , 3 0}$ & D \\
\hline BP48 & 2,184 & 17,64 & 9,06 & 1,17 & $\mathbf{0 , 3 1}$ & D \\
\hline BP49 & 2,284 & 19,38 & 13,78 & 0,22 & $\mathbf{0 , 3 2}$ & D \\
\hline BP50 & 2,015 & 12,46 & 6,09 & 0,83 & 0,46 & $\mathrm{C}$ \\
\hline BP51 & 1,450 & 10,56 & 5,88 & 0,87 & 0,48 & $\mathrm{C}$ \\
\hline BP52 & 1,545 & 10,74 & 9,24 & 0,28 & $\mathbf{0 , 3 1}$ & D \\
\hline BP53 & 1,571 & 11,63 & 11,53 & 0,27 & 0,26 & D \\
\hline BP54 & 2,759 & 26,07 & 14,84 & 0,71 & $\mathbf{0 , 1 9}$ & $E$ \\
\hline BP55 & 1,818 & 15,25 & 11,35 & 0,51 & 0,25 & $\mathrm{E}$ \\
\hline BP56 & 2,065 & 20,00 & 10,55 & 0,67 & 0,27 & D \\
\hline BP57 & 3,049 & 23,61 & 12,17 & 0,95 & 0,23 & $\mathrm{E}$ \\
\hline BP58 & 2,664 & 25,32 & 13,24 & 0,88 & 0,21 & $E$ \\
\hline BP59 & 0,889 & 4,73 & 6,20 & 0,74 & 0,64 & B \\
\hline BP60 & 1,548 & 11,54 & 10,47 & 0,65 & $\mathbf{0 , 2 7}$ & D \\
\hline BP61 & 2,310 & 19,65 & 11,21 & 0,49 & 0,25 & $\mathrm{E}$ \\
\hline BP62 & 1,659 & 7,26 & 6,74 & 1,03 & 0,42 & C \\
\hline BP63 & 1,471 & 6,46 & 5,53 & 1,42 & $\mathbf{0 , 5 1}$ & B \\
\hline BP64 & 1,711 & 8,10 & 6,63 & 1,53 & 0,43 & $\mathrm{C}$ \\
\hline BP65 & 0,837 & 6,00 & 9,07 & 0,13 & 0,54 & B \\
\hline ВP66 & 0,812 & 9,77 & 6,96 & 0,07 & 1,00 & $\mathrm{~A}$ \\
\hline BP67 & 0,610 & 8,17 & 5,19 & 0,15 & 0,68 & B \\
\hline BP68 & 0,412 & 3,01 & 2,82 & 0,07 & 1,00 & A \\
\hline BP69 & 0,773 & 16,75 & 8,73 & 0,08 & $\mathbf{0 , 8 8}$ & A \\
\hline BP70 & 0,754 & 13,58 & 7,23 & 0,09 & 0,78 & A \\
\hline BP71 & 0,478 & 5,10 & 3,68 & 0,08 & $\mathbf{0 , 8 8}$ & A \\
\hline BP72 & 0,611 & 8,17 & 5,19 & 0,09 & 0,78 & $\mathrm{~A}$ \\
\hline
\end{tabular}

The DEA results indicate that of the 72 analyzed products, 4 are efficient and present a score equal to 1

318 (BP43, BP44, BP66 and BP68), which are then the efficient DMUs. Another 9 products do not present efficiency 319 indicators equal to 1 but were also allocated in performance category A, based on cluster analysis, being the lowest 320 value 0,78 . At the same time, 9 products were considered the most inefficient and were classified in category $\mathrm{E}$ 321 (BP20, BP22, BP28, BP40, BP54, BP55, BP57, BP58 and BP61), with the lowest values being equal to 0,19.

As for the application of the framework, some particular products can be highlighted in order to observe 323 how the DEA handled the trade-offs between the indicators. For example, the products BP49, BP52 and BP53 324 present reduced LCIA indicator values in the POCP category $(0,22,0,28$ and 0,27 , respectively) compared to the 325 highest values for this category $(1,42)$. However, as their indicators for other categories are above average, they are 326 classified as category D products. On the other hand, BP18 and BP19 present above-average values for POCP $(0,92$ 327 and 0,91 , respectively), but also show reduced values in the other categories, especially AP, where they present 
values close to the lowest in the category (3,57 and 3,54, respectively). Thus, despite below-average performance in one of the categories, they are still classified as Category A products.

For this category, in the 89 products analyzed the functional unit presented in the documents is "Providing a thermal insulation of $1 \mathrm{~m}^{2}$ with a thermal resistance equal to $1,0 \mathrm{~K} \cdot \mathrm{m}^{2} . \mathrm{W}^{-1}$ " and the category includes, for example, glass wool, mineral wool and thermal panels. Regarding the LCIA indicators, seven categories of environmental impacts were evaluated, as follows:

- Global Warming Potential (GWP), in $\mathrm{kg} \mathrm{CO}_{2}$ equivalent;

- Ozone Layer Depletion Potential (ODP), in g CFC11 equivalent. $10^{-4}$,

- Acidification Potential (AP), in $\mathrm{g} \mathrm{SO}_{2}$ equivalent;

- Eutrophication Potential (EP), in $\mathrm{g} \mathrm{PO}_{4}{ }^{-}$equivalent;

- Photochemical Ozone Creation Potentials (POCP), in $\mathrm{g}_{2} \mathrm{H}_{4}$ equivalent;

- Abiotic Depletion Potential for Non-fossil Resources, Elements (ADPE), in kg Sb equivalent;

- Abiotic Depletion Potential for Fossil Resources (ADPF), in MJ.

Statistical analyzes do not verify variables with linear correlations greater than 0,9 between them, as can be

observed in Table 1. Thus, the 7 indicators are used as inputs for the application of DEA.

The values obtained for each impact category, as well as the results of DEA and classification proposed

Table 3: Indicators of LCIA (GWP, ODP, AP, EP, POCP, ADPE and ADPF), DEA and classification (letter and coloring), considering modules A1-A3 of EPDs of insulation materials.

\begin{tabular}{|c|c|c|c|c|c|c|c|c|c|}
\hline & $\begin{array}{c}\text { GWP } \\
\left(\mathrm{kg} \mathrm{CO}_{2} \mathrm{eq}\right)\end{array}$ & $\begin{array}{c}\text { ODP } \\
\left(\mathrm{g} \mathrm{CFC11} \mathrm{eq} \cdot 10^{-4}\right)\end{array}$ & $\begin{array}{c}\mathrm{AP} \\
\left(\mathrm{g} \mathrm{SO}_{2} \mathrm{eq}\right)\end{array}$ & $\begin{array}{c}\mathbf{E P} \\
\left(\mathrm{g} \mathrm{PO}_{4}{ }^{-} \text {eq }\right)\end{array}$ & $\begin{array}{c}\text { POCP } \\
\left(\mathrm{g} \mathrm{C}_{2} \mathrm{H}_{4} \text { eq) }\right.\end{array}$ & $\begin{array}{l}\text { ADPE } \\
\text { (g Sb eq) }\end{array}$ & $\begin{array}{c}\text { ADPF } \\
(\mathbf{M J})\end{array}$ & DEA & CLASS \\
\hline IM01 & 15,515 & 12,930 & 41,653 & 7,840 & 8,570 & 6,031 & 119,480 & 0,069 & E \\
\hline IM02 & 17,659 & 13,030 & 48,863 & 8,794 & 9,665 & 6,031 & 177,510 & 0,046 & E \\
\hline IM03 & 13,698 & 11,426 & 36,924 & 6,959 & 7,580 & 5,341 & 105,960 & $\mathbf{0 , 0 7 7}$ & D \\
\hline IM04 & 15,592 & 11,526 & 43,234 & 7,782 & 8,555 & 5,341 & 156,980 & 0,052 & E \\
\hline IM05 & 12,837 & 10,725 & 34,403 & 6,487 & 7,066 & 4,970 & 98,590 & $\mathbf{0 , 0 8 3}$ & D \\
\hline IM06 & 14,599 & 10,825 & 40,313 & 7,250 & 7,971 & 4,970 & 146,710 & 0,056 & E \\
\hline IM07 & 11,981 & 9,973 & 32,105 & 6,067 & 6,589 & 4,640 & 92,040 & $\mathbf{0 , 0 8 9}$ & D \\
\hline IM08 & 13,626 & 10,023 & 37,605 & 6,770 & 7,435 & 4,640 & 136,460 & 0,060 & E \\
\hline IM09 & 16,587 & 13,932 & 44,689 & 8,436 & 9,178 & 6,461 & 127,790 & 0,064 & E \\
\hline IM10 & 18,885 & 14,032 & 52,299 & 9,430 & 10,352 & 6,461 & 189,820 & 0,043 & E \\
\hline IM11 & 14,662 & 12,328 & 39,546 & 7,462 & 8,122 & 5,721 & 113,240 & 0,072 & D \\
\hline IM12 & 17,659 & 13,030 & 48,863 & 8,794 & 9,665 & 6,031 & 177,510 & 0,046 & E \\
\hline IM13 & 13,696 & 11,426 & 36,823 & 6,948 & 7,571 & 5,331 & 105,950 & $\mathbf{0 , 0 7 7}$ & D \\
\hline IM14 & 15,582 & 11,526 & 43,133 & 7,771 & 8,536 & 5,331 & 156,980 & 0,052 & E \\
\hline IM15 & 14,766 & 12,329 & 39,759 & 7,503 & 8,159 & 5,751 & 113,260 & 0,072 & D \\
\hline IM16 & 16,808 & 12,429 & 46,569 & 8,386 & 9,204 & 5,751 & 169,290 & 0,048 & E \\
\hline IM17 & 12,734 & 10,625 & 34,302 & 6,476 & 7,047 & 4,960 & 98,170 & $\mathbf{0 , 0 8 3}$ & D \\
\hline IM18 & 14,488 & 10,725 & 40,112 & 7,229 & 7,943 & 4,960 & 145,700 & 0,056 & E \\
\hline
\end{tabular}




\begin{tabular}{|c|c|c|c|c|c|c|c|c|c|}
\hline IM19 & 13,806 & 11,527 & 37,238 & 7,032 & 7,655 & 5,391 & 107,000 & $\mathbf{0 , 0 7 7}$ & $\mathrm{D}$ \\
\hline IM20 & 15,714 & 11,627 & 43,648 & 7,865 & 8,640 & 5,391 & 158,020 & $\mathbf{0 , 0 5 2}$ & E \\
\hline IM21 & 11,125 & 9,261 & 29,797 & 5,633 & 6,122 & 4,310 & 85,600 & $\mathbf{0 , 0 9 6}$ & D \\
\hline IM22 & 12,653 & 9,341 & 34,907 & 6,295 & 6,908 & 4,310 & 127,220 & 0,064 & E \\
\hline IM23 & 11,986 & 10,023 & 32,308 & 6,099 & 6,636 & 4,670 & 92,670 & $\mathbf{0 , 0 8 8}$ & D \\
\hline IM24 & 13,647 & 10,123 & 37,818 & 6,822 & 7,482 & 4,670 & 137,490 & $\mathbf{0 , 0 6 0}$ & E \\
\hline IM25 & 11,125 & 9,261 & 29,797 & 5,633 & 6,122 & 4,310 & 85,600 & $\mathbf{0 , 0 9 6}$ & D \\
\hline IM26 & 12,653 & 9,341 & 34,907 & 6,295 & 6,908 & 4,310 & 127,220 & 0,064 & E \\
\hline IM27 & 9,993 & 8,339 & 26,855 & 5,070 & 5,514 & 3,880 & 77,283 & $\mathbf{0 , 1 0 6}$ & D \\
\hline IM28 & 11,367 & 8,409 & 31,463 & 5,662 & 6,221 & 3,880 & 114,903 & $\mathbf{0 , 0 7 1}$ & E \\
\hline IM29 & 9,628 & 8,029 & 25,908 & 4,879 & 5,309 & 3,730 & 74,471 & $\mathbf{0 , 1 1 0}$ & $\mathrm{C}$ \\
\hline IM30 & 11,367 & 8,409 & 31,463 & 5,662 & 6,221 & 3,880 & 114,903 & $\mathbf{0 , 0 7 1}$ & D \\
\hline IM31 & 3,980 & 0,915 & 15,700 & 1,840 & 0,939 & 0,002 & 88,200 & 0,286 & $\mathrm{C}$ \\
\hline IM32 & 1,260 & 0,696 & 8,890 & 1,560 & 0,370 & 0,001 & 19,300 & 0,492 & B \\
\hline IM33 & 3,400 & 3,000 & 34,000 & 5,300 & 1,200 & 0,001 & 52,000 & $\mathbf{0 , 1 5 8}$ & $\mathrm{C}$ \\
\hline IM34 & 1,500 & 1,200 & 20,000 & 2,600 & 0,870 & 0,001 & 23,000 & 0,356 & B \\
\hline IM35 & 5,120 & 65,300 & 114,000 & 19,200 & 4,480 & 0,001 & 78,300 & 0,116 & $\mathrm{C}$ \\
\hline IM36 & 7,440 & 8,850 & 79,500 & 8,970 & 4,360 & 0,002 & 119,000 & 0,069 & E \\
\hline IM37 & 5,600 & 6,300 & 53,000 & 8,000 & 2,100 & 0,002 & 83,000 & 0,099 & $\mathrm{D}$ \\
\hline IM38 & 8,080 & 10,400 & 83,300 & 9,230 & 4,490 & 0,002 & 128,000 & 0,064 & E \\
\hline IM39 & 1,940 & 1,710 & 22,400 & 2,710 & 1,180 & 0,001 & 30,000 & 0,321 & $\mathrm{C}$ \\
\hline IM40 & 2,100 & 1,500 & 22,000 & 2,900 & 1,100 & 0,001 & 33,000 & 0,259 & $\mathrm{C}$ \\
\hline IM41 & 0,740 & 0,530 & 34,000 & 0,570 & 0,330 & 0,001 & 15,000 & 0,660 & B \\
\hline IM42 & 0,900 & 1,300 & 4,800 & 0,550 & 0,360 & 0,001 & 17,000 & 0,725 & B \\
\hline IM43 & 0,570 & 0,270 & 2,400 & 0,430 & 0,170 & 0,001 & 11,000 & 1,000 & A \\
\hline IM44 & 0,870 & 0,350 & 4,100 & 0,440 & 0,430 & 0,001 & 16,000 & 0,789 & A \\
\hline IM45 & 3,200 & 1,300 & 15,000 & 1,800 & 1,800 & 0,002 & 60,000 & 0,207 & $\mathrm{C}$ \\
\hline IM46 & 2,900 & 1,200 & 13,000 & 1,600 & 1,700 & 0,002 & 56,000 & 0,228 & $\mathrm{C}$ \\
\hline IM47 & 4,700 & 5,600 & 26,000 & 2,600 & 2,900 & 0,003 & 88,000 & 0,128 & $\mathrm{C}$ \\
\hline IM48 & 1,400 & 0,550 & 6,300 & 0,690 & 0,660 & 0,001 & 26,000 & 0,498 & B \\
\hline IM49 & 0,680 & 0,270 & 3,200 & 0,340 & 0,320 & 0,001 & 13,000 & 1,000 & A \\
\hline IM50 & 1,100 & 2,000 & 6,900 & 0,520 & 0,590 & 0,001 & 21,000 & 0,638 & B \\
\hline IM51 & 1,100 & 2,000 & 6,900 & 0,520 & 0,590 & 0,001 & 21,000 & $\mathbf{0 , 6 3 8}$ & B \\
\hline IM52 & 0,730 & 0,490 & 3,600 & 0,430 & 0,350 & 0,001 & 13,000 & 0,776 & A \\
\hline IM53 & 2,900 & 1,700 & 14,000 & 2,400 & 1,500 & 0,002 & 60,000 & 0,182 & $\mathrm{C}$ \\
\hline IM54 & 0,990 & 0,250 & 6,700 & 1,100 & 0,210 & 0,001 & 15,000 & $\mathbf{0 , 9 7 5}$ & A \\
\hline IM55 & 1,300 & 1,150 & 15,000 & 1,850 & 0,750 & 0,001 & 20,500 & 0,469 & B \\
\hline IM56 & 0,432 & 0,406 & 2,240 & 0,332 & 0,097 & 0,001 & 8,190 & 1,000 & A \\
\hline IM57 & 1,400 & 1,900 & 13,000 & 1,900 & 0,500 & 0,001 & 20,000 & 0,441 & B \\
\hline IM58 & 4,100 & 3,500 & 35,000 & 5,600 & 1,400 & 0,001 & 61,000 & $\mathbf{0 , 1 3 8}$ & $\mathrm{C}$ \\
\hline IM59 & 3,600 & 3,100 & 33,000 & 5,400 & 1,200 & 0,001 & 52,000 & $\mathbf{0 , 1 5 9}$ & $\mathrm{C}$ \\
\hline IM60 & 4,550 & 2,640 & 33,200 & 5,450 & 1,410 & 0,001 & 72,700 & $\mathbf{0 , 1 3 0}$ & $\mathrm{C}$ \\
\hline IM61 & 6,510 & 4,230 & 39,000 & 7,370 & 2,090 & 0,007 & 112,000 & $\mathbf{0 , 0 8 3}$ & $\mathrm{D}$ \\
\hline IM62 & 4,300 & 2,400 & 18,000 & 3,300 & 2,200 & 0,002 & 86,000 & $\mathbf{0 , 1 3 1}$ & $\mathrm{C}$ \\
\hline IM63 & 0,960 & 0,240 & 6,500 & 1,000 & 0,210 & 0,001 & 15,000 & 1,000 & A \\
\hline IM64 & 21,400 & 14,100 & 86,700 & 18,100 & 3,940 & 0,023 & 191,000 & 0,043 & E \\
\hline IM65 & 10,100 & 7,310 & 41,800 & 9,820 & 1,950 & 0,013 & 102,000 & $\mathbf{0 , 0 8 0}$ & D \\
\hline IM66 & 1,100 & 0,280 & 7,700 & 1,300 & 0,240 & 0,001 & 17,000 & $\mathbf{0 , 8 6 5}$ & A \\
\hline IM67 & 1,500 & 0,390 & 11,000 & 1,700 & 0,330 & 0,001 & 23,000 & 0,627 & B \\
\hline IM68 & 2,920 & 2,310 & 0,794 & 18,600 & 5,240 & 27,700 & 51,100 & 1,000 & A \\
\hline IM69 & 4,700 & 0,690 & 19,000 & 6,200 & 1,400 & 0,017 & 89,000 & 0,348 & B \\
\hline IM70 & 4,400 & 0,550 & 18,000 & 5,300 & 1,200 & 0,014 & 84,000 & 0,436 & B \\
\hline IM71 & 8,200 & 1,500 & 33,000 & 12,000 & 2,600 & 0,038 & 150,000 & 0,165 & $\mathrm{C}$ \\
\hline IM72 & 6,400 & 1,600 & 26,000 & 9,700 & 2,100 & 0,029 & 110,000 & 0,161 & $\mathrm{C}$ \\
\hline IM73 & 9,500 & 2,600 & 38,000 & 17,000 & 3,600 & 0,066 & 160,000 & $\mathbf{0 , 1 0 0}$ & $\mathrm{D}$ \\
\hline IM74 & 5,200 & 0,920 & 21,000 & 7,700 & 1,600 & 0,023 & 97,000 & 0,268 & $\mathrm{C}$ \\
\hline IM75 & 15,000 & 4,700 & 58,000 & 29,000 & 6,100 & 0,120 & 240,000 & 0,056 & $\mathrm{E}$ \\
\hline IM76 & 11,000 & 3,000 & 42,000 & 20,000 & 4,100 & 0,078 & 180,000 & $\mathbf{0 , 0 8 7}$ & $\mathrm{D}$ \\
\hline IM77 & 6,400 & 1,400 & 25,000 & 9,900 & 2,100 & 0,033 & 120,000 & 0,182 & $\mathrm{C}$ \\
\hline IM78 & 5,090 & 1,480 & 22,600 & 8,370 & 1,300 & 0,005 & 110,000 & $\mathbf{0 , 1 7 5}$ & $\mathrm{C}$ \\
\hline IM79 & 3,890 & 1,130 & 17,200 & 6,390 & 0,990 & 0,004 & 83,900 & 0,229 & $\mathrm{C}$ \\
\hline IM80 & 3,760 & 2,450 & 13,500 & 6,450 & 1,070 & 0,001 & 66,400 & 0,166 & $\mathrm{C}$ \\
\hline IM81 & 1,920 & 1,250 & 6,890 & 3,300 & 0,548 & 0,001 & 33,900 & $\mathbf{0 , 3 2 5}$ & B \\
\hline IM82 & 1,570 & 1,020 & 5,620 & 2,690 & 0,447 & 0,001 & 27,700 & $\mathbf{0 , 3 9 9}$ & B \\
\hline IM83 & 1,380 & 0,897 & 4,950 & 2,360 & 0,393 & 0,001 & 24,300 & $\mathbf{0 , 4 5 3}$ & B \\
\hline IM84 & 1,190 & 0,775 & 4,270 & 2,040 & 0,340 & 0,001 & 21,000 & $\mathbf{0 , 5 2 5}$ & B \\
\hline
\end{tabular}




\begin{tabular}{|c|c|c|c|c|c|c|c|c|c|}
\hline IM85 & 0,990 & 0,644 & 3,550 & 1,700 & 0,284 & 0,001 & 17,500 & 0,631 & B \\
\hline IM86 & 2,311 & 0,882 & 7,357 & 1,372 & 15,883 & 0,001 & 55,134 & 0,324 & B \\
\hline IM87 & 1,991 & 0,773 & 6,373 & 1,197 & 13,447 & 0,001 & 47,344 & $\mathbf{0 , 3 7 3}$ & B \\
\hline IM88 & 12,800 & 27,400 & 65,200 & 5,930 & 3,740 & 0,082 & 99,100 & 0,083 & D \\
\hline IM89 & 12,300 & 33,900 & 58,100 & 5,940 & 4,080 & 0,049 & 91,300 & 0,090 & D \\
\hline
\end{tabular}

In the case of insulation materials, 5 products (IM42, IM49, IM56, IM63 and IM68) are considered efficient (score equal to 1) and along with 4 other products (IM44, IM52, IM54 and IM66) form the category A. The 20 products that present scores less than 0,071 are considered the least efficient and classified in category E. Other 20 products are placed in category $\mathrm{D}$ (values of 0,072 to 0,106$), 21$ products in category $\mathrm{C}(0,110$ to 0,321 ) and 19 in category B $(0,324$ to 0,725$)$.

Here there is also the occurrence of trade-offs under which the DEA approach can be highlighted, especially regarding the categories ADPF, ADPE and POCP. For example, for IM35, IM36, IM37 and IM38 there is a reduced value in the indicators for ADPF and, however, these DMUs are considered inefficient and allocated in categories C, E, D and E, respectively. As for ADPE, one of the DMUs considered efficient was IM68, although it presents the highest value for this product category $(0,0277)$, which is compensated by the good performance in other categories, such as GWP and AP. On the other hand, IM86 and IM87 present the lowest values in the POCP category, which are partially compensated by above-average performance in the other categories, which place them in the classification B.

\subsection{Comparison between DEA and other single score methods}

In order to verify the product ranking and classification under different approaches, a comparison between

372 the results obtained through i) DEA, ii) external normalization + aggregation of impact categories and iii) internal

373 normalization + aggregation of impact categories is presented. For the external normalization, the normalization

374 factors of the CML-IA method (Oers 2015) are used. In the internal normalization, the highest values among the 375 results in each of the impact categories are used as factors. The results of the application of these factors for bakery 376 products and the subsequent ranking obtained through cluster analysis are presented in Table 4. with aggregation.

\begin{tabular}{l|cccccc}
\multicolumn{1}{c}{} & DEA & CLASS & $\begin{array}{c}\text { EXT. } \\
\text { NORM. }\end{array}$ & CLASS & $\begin{array}{c}\text { INT. } \\
\text { NORM. }\end{array}$ & CLASS \\
\hline BP19 & 0,187 & E & 6,761 & E & 0,787 & E \\
BP40 & 0,190 & E & 5,882 & D & 0,677 & E \\
BP54 & 0,190 & E & 7,192 & E & 0,839 & E \\
BP58 & 0,213 & E & 6,920 & E & 0,825 & E \\
BP22 & 0,215 & E & 6,131 & E & 0,717 & E \\
BP28 & 0,232 & E & 6,130 & E & 0,730 & E \\
BP57 & 0,232 & E & 6,847 & E & 0,834 & E \\
BP55 & 0,248 & E & 4,814 & D & 0,567 & D \\
BP61 & 0,252 & E & 5,531 & D & 0,644 & E \\
BP53 & 0,262 & D & 4,155 & C & 0,476 & C \\
BP23 & 0,264 & D & 4,490 & C & 0,517 & D \\
BP29 & 0,266 & D & 5,327 & D & 0,655 & E \\
BP56 & 0,267 & D & 5,440 & D & 0,646 & E \\
BP26 & 0,269 & D & 5,406 & D & 0,655 & E
\end{tabular}




\begin{tabular}{|c|c|c|c|c|c|c|}
\hline BP60 & 0,269 & D & 4,223 & $\mathrm{C}$ & 0,518 & D \\
\hline BP31 & 0,270 & D & 4,421 & $\mathrm{C}$ & 0,519 & $\mathrm{D}$ \\
\hline BP36 & 0,272 & D & 4,327 & $\mathrm{C}$ & 0,506 & D \\
\hline BP35 & 0,288 & D & 3,956 & $\mathrm{C}$ & 0,454 & $\mathrm{C}$ \\
\hline BP37 & 0,296 & D & 3,828 & $\mathrm{C}$ & 0,438 & $\mathrm{C}$ \\
\hline BP41 & 0,300 & D & 3,952 & $\mathrm{C}$ & 0,461 & $\mathrm{C}$ \\
\hline ВР09 & 0,303 & D & 4,028 & $\mathrm{C}$ & 0,469 & $\mathrm{C}$ \\
\hline BP47 & 0,303 & D & 5,098 & D & 0,629 & E \\
\hline ВР06 & 0,304 & D & 4,372 & $\mathrm{C}$ & 0,499 & D \\
\hline BP52 & 0,305 & D & 3,691 & $\mathrm{C}$ & 0,429 & $\mathrm{C}$ \\
\hline BP48 & 0,311 & $\mathrm{D}$ & 5,368 & D & 0,690 & E \\
\hline BP49 & 0,318 & D & 5,710 & D & 0,638 & $\mathrm{E}$ \\
\hline BP25 & 0,324 & D & 5,079 & D & 0,625 & $\mathrm{E}$ \\
\hline BP27 & 0,324 & D & 5,079 & D & 0,625 & E \\
\hline BP12 & 0,334 & D & 3,657 & $\mathrm{C}$ & 0,425 & $\mathrm{C}$ \\
\hline ВP08 & 0,346 & D & 3,328 & B & 0,383 & B \\
\hline BP24 & 0,357 & $\mathrm{C}$ & 3,898 & $\mathrm{C}$ & 0,497 & D \\
\hline BP33 & 0,362 & $\mathrm{C}$ & 4,606 & $\mathrm{C}$ & 0,635 & E \\
\hline BP13 & 0,366 & $\mathrm{C}$ & 3,631 & $\mathrm{C}$ & 0,451 & $\mathrm{C}$ \\
\hline BP10 & 0,385 & $\mathrm{C}$ & 3,122 & B & 0,359 & B \\
\hline BP32 & 0,386 & $\mathrm{C}$ & 4,280 & $\mathrm{C}$ & 0,591 & D \\
\hline BP11 & 0,392 & $\mathrm{C}$ & 3,069 & B & 0,354 & B \\
\hline BP21 & 0,397 & $\mathrm{C}$ & 3,713 & $\mathrm{C}$ & 0,467 & $\mathrm{C}$ \\
\hline BP46 & 0,415 & $\mathrm{C}$ & 3,364 & B & 0,392 & B \\
\hline BP62 & 0,418 & $\mathrm{C}$ & 3,508 & $\mathrm{C}$ & 0,486 & $\mathrm{C}$ \\
\hline BP64 & 0,425 & $\mathrm{C}$ & 3,949 & $\mathrm{C}$ & 0,578 & D \\
\hline BP38 & 0,436 & $\mathrm{C}$ & 3,493 & $\mathrm{C}$ & 0,448 & $\mathrm{C}$ \\
\hline BP30 & 0,441 & $\mathrm{C}$ & 3,158 & B & 0,372 & B \\
\hline BP39 & 0,445 & $\mathrm{C}$ & 3,498 & $\mathrm{C}$ & 0,454 & $\mathrm{C}$ \\
\hline BP50 & 0,463 & $\mathrm{C}$ & 4,024 & $\mathrm{C}$ & 0,521 & D \\
\hline BP42 & 0,472 & $\mathrm{C}$ & 2,954 & B & 0,393 & B \\
\hline BP51 & 0,480 & $\mathrm{C}$ & 3,515 & $\mathrm{C}$ & 0,464 & $\mathrm{C}$ \\
\hline BP63 & 0,510 & B & 3,387 & B & 0,506 & D \\
\hline BP34 & 0,531 & B & 3,721 & C & 0,516 & D \\
\hline BP01 & 0,532 & B & 3,032 & B & 0,403 & B \\
\hline BP16 & 0,538 & B & 2,547 & B & 0,285 & A \\
\hline BP65 & 0,538 & B & 2,647 & B & 0,298 & B \\
\hline ВР02 & 0,563 & B & 2,841 & B & 0,383 & B \\
\hline BP17 & 0,596 & B & 1,905 & A & 0,218 & A \\
\hline BP59 & 0,636 & B & 2,505 & B & 0,342 & B \\
\hline BP45 & 0,642 & B & 2,110 & A & 0,259 & A \\
\hline BP14 & 0,654 & B & 1,947 & $\mathrm{~A}$ & 0,224 & A \\
\hline BP15 & 0,659 & B & 1,851 & $\mathrm{~A}$ & 0,210 & A \\
\hline ВP07 & 0,668 & B & 1,775 & $\mathrm{~A}$ & 0,203 & A \\
\hline BP67 & 0,675 & B & 2,140 & A & 0,239 & A \\
\hline BP03 & 0,778 & A & 1,922 & $\mathrm{~A}$ & 0,213 & A \\
\hline ВP04 & 0,778 & A & 1,625 & A & 0,183 & A \\
\hline BP05 & 0,778 & A & 1,665 & A & 0,186 & A \\
\hline BP70 & 0,778 & A & 3,072 & B & 0,327 & B \\
\hline BP72 & 0,778 & A & 2,099 & A & 0,229 & A \\
\hline BP18 & 0,843 & A & 2,445 & B & 0,358 & B \\
\hline BP12 & 0,850 & A & 2,423 & B & 0,355 & B \\
\hline BP69 & 0,875 & A & 3,646 & $\mathrm{C}$ & 0,382 & B \\
\hline BP71 & 0,875 & A & 1,453 & A & 0,162 & A \\
\hline BP43 & 1,000 & A & 2,197 & $\mathrm{~A}$ & 0,247 & A \\
\hline BP44 & 1,000 & A & 2,177 & A & 0,244 & A \\
\hline ВР66 & 1,000 & A & 2,652 & B & 0,287 & A \\
\hline BP68 & 1,000 & A & 1,053 & A & 0,121 & A \\
\hline
\end{tabular}

It is possible to identify some similarity in the results in the 3 different approaches, which can also be 382 verified through the linear correlation between the values. For both DEA and external normalization and for DEA 383 and internal normalization, there is a $-0,81$ correlation between the results. However, it is also possible to identify 384 significant differences in the clusters formed in the three approaches, especially in cases involving trade-offs, such 385 as BP69, for example, where there are different rankings in each of the approaches adopted. For BP69, values close 
to the efficiency frontier for GWP and POCP make DEA results high for this product $(0,875)$ and should to be considered in category A, despite the fact that the values for AP and EP are below average. In the other approaches, these low values result in significant contributions for the formation of the aggregated single score, and therefore, this product is classified in category $\mathrm{B}$, when using internal normalization, and in $\mathrm{C}$ when using external normalization. The input-oriented model of DEA seeks to verify whether a DMU can potentially reduce its current input and still produce the same amount of inputs (Zhu 2015). So, if a DMU is close to the efficiency frontier in some categories, the product has a high rating for DEA, since it is considered that it is already close to the overall target DMU, established by the best practices of the current dataset.

As for the material insulation, the results are shown in Table 5. normalization with aggregation.

\begin{tabular}{|c|c|c|c|c|c|c|}
\hline & DEA & CLASS & $\begin{array}{c}\text { EXT. } \\
\text { NORM. }\end{array}$ & CLASS & $\begin{array}{c}\text { INT. } \\
\text { NORM. }\end{array}$ & CLASS \\
\hline IM10 & 0,043 & E & 2,773 & E & 0,508 & E \\
\hline IM64 & 0,043 & E & 0,238 & D & 0,521 & E \\
\hline IM02 & 0,046 & E & 2,588 & E & 0,475 & E \\
\hline IM12 & 0,046 & E & 2,588 & E & 0,475 & E \\
\hline IM16 & 0,048 & $\mathrm{E}$ & 2,468 & $\mathrm{E}$ & 0,452 & E \\
\hline IM04 & 0,052 & $\mathrm{E}$ & 2,292 & $\mathrm{E}$ & 0,420 & E \\
\hline IM14 & 0,052 & $\mathrm{E}$ & 2,288 & $\mathrm{E}$ & 0,419 & E \\
\hline IM20 & 0,052 & E & 2,313 & E & 0,423 & E \\
\hline IM06 & 0,056 & E & 2,134 & $\mathrm{E}$ & 0,392 & D \\
\hline IM18 & 0,056 & $\mathrm{E}$ & 2,129 & $\overline{\mathrm{E}}$ & 0,390 & D \\
\hline IM75 & 0,056 & E & 0,273 & D & 0,524 & E \\
\hline IM08 & 0,060 & E & 1,992 & $\mathrm{E}$ & 0,365 & D \\
\hline IM24 & 0,060 & $\mathrm{E}$ & 2,005 & E & 0,367 & D \\
\hline IM09 & 0,064 & E & 2,732 & E & 0,431 & E \\
\hline IM22 & 0,064 & E & 1,850 & $\mathrm{E}$ & 0,340 & D \\
\hline IM26 & 0,064 & E & 1,850 & E & 0,340 & D \\
\hline IM38 & 0,064 & E & 0,153 & $\mathrm{C}$ & 0,343 & D \\
\hline IM01 & 0,069 & E & 2,550 & $\mathrm{E}$ & 0,402 & D \\
\hline IM36 & 0,069 & E & 0,144 & E & 0,323 & D \\
\hline IM28 & 0,071 & E & 1,666 & $\mathrm{E}$ & 0,306 & D \\
\hline IM30 & 0,071 & D & 1,666 & E & 0,306 & $\mathrm{D}$ \\
\hline IM11 & 0,072 & D & 2,419 & $\mathrm{E}$ & 0,381 & D \\
\hline IM15 & 0,072 & D & 2,431 & E & 0,383 & D \\
\hline IM03 & 0,077 & D & 2,258 & E & 0,356 & D \\
\hline IM13 & 0,077 & D & 2,254 & E & 0,355 & $\mathrm{D}$ \\
\hline IM19 & 0,077 & D & 2,279 & $\mathrm{E}$ & 0,359 & D \\
\hline IM65 & 0,080 & D & 0,119 & $\mathrm{C}$ & 0,262 & C \\
\hline IM05 & 0,083 & $\mathrm{D}$ & 2,102 & $\mathrm{E}$ & 0,332 & $\mathrm{D}$ \\
\hline IM17 & 0,083 & D & 2,097 & $\mathrm{E}$ & 0,331 & D \\
\hline IM61 & 0,083 & D & 0,105 & B & 0,223 & $\mathrm{C}$ \\
\hline IM88 & 0,083 & D & 0,174 & $\mathrm{C}$ & 0,349 & D \\
\hline IM76 & 0,087 & $\mathrm{D}$ & 0,195 & $\mathrm{C}$ & 0,376 & D \\
\hline IM23 & 0,088 & D & 1,975 & $\mathrm{E}$ & 0,311 & D \\
\hline IM07 & 0,089 & D & 1,962 & E & 0,310 & D \\
\hline IM89 & 0,090 & D & 0,153 & $\mathrm{C}$ & 0,350 & $\mathrm{D}$ \\
\hline IM21 & 0,096 & D & 1,823 & E & 0,288 & $\mathrm{C}$ \\
\hline IM25 & 0,096 & D & 1,823 & E & 0,288 & $\mathrm{C}$ \\
\hline IM37 & 0,099 & $\mathrm{D}$ & 0,099 & B & 0,225 & $\mathrm{C}$ \\
\hline IM73 & 0,100 & D & 0,171 & $\mathrm{C}$ & 0,328 & D \\
\hline IM27 & 0,106 & D & 1,641 & E & 0,259 & C \\
\hline IM29 & 0,110 & $\mathrm{C}$ & 1,578 & $\mathrm{E}$ & 0,250 & C \\
\hline IM35 & 0,116 & $\mathrm{C}$ & 0,154 & $\mathrm{C}$ & 0,501 & $\mathrm{E}$ \\
\hline IM47 & 0,128 & $\mathrm{C}$ & 0,080 & B & 0,167 & B \\
\hline IM60 & 0,130 & $\mathrm{C}$ & 0,074 & B & 0,161 & B \\
\hline IM62 & 0,131 & C & 0,070 & B & 0,144 & B \\
\hline
\end{tabular}




\begin{tabular}{|c|c|c|c|c|c|c|}
\hline IM58 & 0,138 & $\mathrm{C}$ & 0,069 & B & 0,155 & B \\
\hline IM33 & 0,158 & $\mathrm{C}$ & 0,061 & B & 0,140 & B \\
\hline IM59 & 0,159 & $\mathrm{C}$ & 0,062 & B & 0,141 & B \\
\hline IM72 & 0,161 & $\mathrm{C}$ & 0,107 & B & 0,211 & $\mathrm{C}$ \\
\hline IM71 & 0,165 & $\mathrm{C}$ & 0,140 & $\mathrm{C}$ & 0,271 & $\mathrm{C}$ \\
\hline IM80 & 0,166 & $\mathrm{C}$ & 0,056 & B & 0,128 & B \\
\hline IM78 & 0,175 & $\mathrm{C}$ & 0,087 & B & 0,184 & B \\
\hline IM53 & 0,182 & $\mathrm{C}$ & 0,049 & A & 0,102 & B \\
\hline IM77 & 0,182 & $\mathrm{C}$ & 0,112 & B & 0,216 & $\mathrm{C}$ \\
\hline IM45 & 0,207 & $\mathrm{C}$ & 0,052 & B & 0,104 & B \\
\hline IM46 & 0,228 & $\mathrm{C}$ & 0,047 & A & 0,095 & A \\
\hline IM79 & 0,229 & $\mathrm{C}$ & 0,066 & B & 0,140 & B \\
\hline IM40 & 0,259 & $\mathrm{C}$ & 0,040 & A & 0,089 & A \\
\hline IM74 & 0,268 & $\mathrm{C}$ & 0,089 & B & 0,173 & B \\
\hline IM31 & 0,286 & $\mathrm{C}$ & 0,062 & B & 0,118 & B \\
\hline IM39 & 0,321 & $\mathrm{C}$ & 0,039 & A & 0,087 & A \\
\hline IM88 & 0,324 & B & 0,096 & B & 0,209 & $\mathrm{C}$ \\
\hline IM81 & 0,325 & B & 0,029 & A & 0,066 & A \\
\hline IM69 & 0,348 & B & 0,079 & B & 0,153 & B \\
\hline IM34 & 0,356 & B & 0,032 & A & 0,072 & A \\
\hline IM87 & 0,373 & B & 0,082 & B & 0,178 & B \\
\hline IM82 & 0,399 & B & 0,023 & A & 0,054 & A \\
\hline IM70 & 0,436 & B & 0,072 & B & 0,140 & B \\
\hline IM57 & 0,441 & B & 0,024 & A & 0,056 & A \\
\hline IM83 & 0,453 & B & 0,021 & A & 0,047 & $\mathrm{~A}$ \\
\hline IM55 & 0,469 & B & 0,026 & A & 0,058 & $\mathrm{~A}$ \\
\hline IM31 & 0,492 & B & 0,020 & A & 0,044 & A \\
\hline IM48 & 0,498 & B & 0,022 & A & 0,043 & $\mathrm{~A}$ \\
\hline IM84 & 0,525 & B & 0,018 & A & 0,041 & A \\
\hline IM67 & 0,627 & B & 0,023 & A & 0,050 & $\mathrm{~A}$ \\
\hline IM86 & 0,631 & B & 0,015 & A & 0,034 & $\mathrm{~A}$ \\
\hline IM50 & 0,638 & B & 0,019 & $\mathrm{~A}$ & 0,041 & $\mathrm{~A}$ \\
\hline IM51 & 0,638 & B & 0,019 & A & 0,041 & $\mathrm{~A}$ \\
\hline IM41 & 0,660 & B & 0,030 & $\mathrm{~A}$ & 0,063 & $\mathrm{~A}$ \\
\hline IM42 & 0,725 & B & 0,014 & A & 0,031 & A \\
\hline IM52 & 0,776 & A & 0,011 & A & 0,023 & $\mathrm{~A}$ \\
\hline IM44 & 0,789 & A & 0,014 & A & 0,027 & $\mathrm{~A}$ \\
\hline IM66 & 0,865 & A & 0,017 & A & 0,036 & $\mathrm{~A}$ \\
\hline IM54 & 0,975 & A & 0,015 & A & 0,032 & $\mathrm{~A}$ \\
\hline IM43 & 1,000 & A & 0,009 & A & 0,018 & $\mathrm{~A}$ \\
\hline IM49 & 1,000 & A & 0,011 & A & 0,021 & A \\
\hline IM56 & 1,000 & A & 0,007 & A & 0,014 & $\mathrm{~A}$ \\
\hline IM63 & 1,000 & A & 0,015 & A & 0,031 & A \\
\hline IM68 & 1,000 & A & 11,028 & E & 0,338 & D \\
\hline
\end{tabular}

In this case, a lower similarity between the rankings proposed in each of the approaches is observed, which

400 can be verified by the linear correlations coefficients of $-0,73$ between DEA and internal normalization and $-0,15$

401 between DEA and external normalization. This may be related to the higher number of variables included in the

402 analysis, 7 against 4 for bakery products, which reduces the relative importance of each of the variables for the 403 single score.

404 Also, some products like IM38, IM61 and IM68, can be highlighted, since they assume different rankings 405 in each of the approaches adopted. This may be associated with the fact that these products have very high or low 406 values for one or more categories, for example. Especially in the case of IM68, its relatively high impact value in 407 ADPE makes the normalized indicators for this category very high in relation to the others, which contributes 408 significantly to its high final score. At the same time, in DEA its good performance in other categories compensates 409 this high value, especially for AP, in which IM68 is the "best-in-class", and therefore it is considered efficient, 410 presenting a value equal to 1 . DEA can be sensitive to the presence of outliers among the variables (Cooper et al. 411 2007, Zhu 2015), such as the value for ADPE in IM68, which can explain the different rankings of this product in 
the three different approaches shown. These cases must be identified and analyzed in order to verify the feasibility of their inclusion in the data set, as they may represent limitations to the application of the DEA.

The difference between the DEA technique and the other approaches analyzed lies in the fact that in the first case there is no common defined value to benchmark all products, e.g. the normalization value for ADPE. Instead, an efficiency frontier is established, determined by the DMUs that are part of the sample, which takes into account the variable returns of scale in the analysis and, therefore, each of the inefficient DMUs has its own reference value, related to its projection towards this frontier.

\subsection{Applicability of the suggested framework}

The case studies demonstrate that the proposed framework to benchmark data from EPDs is feasible to be applied for different product categories. Due to the use of DEA, firstly, single scores can be obtained without the use of normalization factors and aggregation, and secondly, trade-offs between impact categories can be dealt with in a way so that inefficiency regarding some categories may be compensated by an efficient indicator in others. The input-oriented approach with variable returns to scale can be useful when LCIA indicators are used as inputs, and the functional/declared unit is used as the single output. Likewise, the cluster analysis allows the establishment of a ranking system based on the efficiency scores.

\section{CONCLUSIONS}

429

In this article, we present a new approach to the use of the results of LCA studies for benchmarking. This system is particularly interesting for data from EPDs since their comparability is ensured by the PCRs under which they are developed. The suggested framework differs from traditional methods of obtaining single scores, e.g., internal normalization with aggregation and external normalization with aggregation. While the absolute normative reference of external normalization and the equalization of indicators through the internal normalization relate the variables with specific values, DEA relates the indicators with an efficiency frontier established by the current dataset assessed. Thus, DEA contributes to the reduction of the use of non-scientific factors in order to obtain a single indicator, since it eliminates the normalization stage and the use of reference values. Although not applied in the two cases, DEA is also flexible to the use of different sets of weights for impact categories, according to the criteria of the decision-makers or to pre-established weighting systems.

The indicators resulting from the DEA can be used, for example, by practitioners, who can benchmark their products in relation to their competitors or within their own company, identifying inefficiencies and opportunities to improve their processes. The framework presented can also be used for communication to final consumers through the production of an indicative label of environmental performance between products of the same category if this can be agreed upon in the industry. Therefore, a ranking based on this technique contributes to benchmark the results of LCA studies and opens a new perspective that addresses the complexity of communicating LCA results. Since methodological diversity is limited by PCRs, DEA contributes to reducing the multidimensionality of results, indicates ways to tackle trade-off issues, and allows comparison of a product among its peers. 
However, it should be noted that DEA is limited to analyzing the efficiency of a given product in relation to a pre-determined group of products. That is, the analysis only indicates that certain products are more efficient in relation to those that are also part of the data set, which does not necessarily mean that they are generally efficient. The entry of a new DMU can establish new efficiency parameters for the group, so a new analysis must be performed. In addition, the limitation to a "cradle-to-gate" analysis may be disregarding important environmental impacts from other stages of the product life cycle. This is particularly important in the analysis of insulation materials or electrical appliances, for example, where most of the environmental impacts are known to typically be concentrated at the use stage.

Regarding product categories, their homogeneity in different EPD schemes may be questioned, since products with distinct characteristics, such as bakery products, which include bread, cakes, cookies and crackers, for example, and therefore, could not be directly compared. We understand that this limitation is not an impediment to the application of the benchmarking system proposed in this paper since in the decision-making process these issues are directed previously to the application of the environmental criterion. That is, the decision maker can be assumed to establish the desired characteristics of the product and then to apply the other selection criteria, such as the environmental performance indicator. Therefore, perhaps no product with a given specific characteristic is considered as efficient overall, but there will be within the broader category an efficiency reference based on a similar functional/declared unit.

In order for the proposed framework to be applied successfully, it is recommended to increase efforts regarding the use of EPDs in several directions. It is important to seek both harmonization of PCRs and greater rigidity and clarity in the guidelines contained in these documents. Too flexible rules may result in different considerations being adopted for products and tend to decrease the applicability of these data for benchmarking. In addition, it is proposed that this framework is adopted in line with the updating of the rules, that is, establishing a period of validity of the environmental performance ranking and, when new data is available, the analysis should be performed again to establish the new efficiency parameters and the new levels for each category. For future studies, it is recommended a practical test of the application of the proposed system to verify the improvement of the communication and the understanding of the environmental indicators.

\section{REFERENCES}

Avadí Á, Vázquez-Rowe I, Fréon P (2014) Eco-efficiency assessment of the Peruvian anchoveta steel and wooden fleets using the LCA x DEA framework. J Clean Prod 70:118-131. https://doi.org/10.1016/j.jclepro.2014.01.047

BIO Intelligence Service (2012) Study on different options for communicating environmental information for products, Final report prepared for the European Commission - DG Environment

Beltrán-Esteve M, Reig-Martínez E, Estruch-Guitart V (2017) Assessing eco-efficiency: a metafrontier directional distance function approach using life cycle analysis. Environ Impact Assess Rev 63:116-127. https://doi.org/10.1016/j.eiar.2017.01.001

Cook WD, Seiford LM, Zhu J (2013) Data envelopment analysis: The research frontier. Omega 41:1-2. https://doi.org/10.1016/j.omega.2012.01.011 
Cooper WW, Seiford LM, Tone K (2007) Data Envelopment Analysis: A Comprehensive text with models, applications, references and DEA-Solver software, 2nd ed. Springer.

Cylus J, Papanicolas I, Smith PC (2017) Using Data Envelopment Analysis to address the challenges of comparing health system efficiency. Glob Policy 8:60-68. https://doi.org/10.1111/1758-5899.12212

Del Borghi A (2013) LCA and communication: Environmental Product Declaration. Int J Life Cycle Assess 18:293295. https://doi.org/10.1007/s11367-012-0513-9

Egilmez G, Gumus S, Kucukvar M, Tatari O (2016) A fuzzy data envelopment analysis framework for dealing with uncertainty impacts of input-output Life Cycle Assessment models on eco-efficiency assessment. J Clean Prod 129: 622-636. https://doi.org/10.1016/j.jclepro.2016.03.111

Egilmez G, Kucukvar M, Tatari O, Bhutta MKS (2014). Supply chain sustainability assessment of the U.S. food manufacturing sectors: a life cycle-based frontier approach. Resour Conserv Recycl 82:8-20. https://doi.org/10.1016/j.resconrec.2013.10.008

Environdec (2012) Product Category Rules for Bakery Products (2012:06) version 2.0

Environdec (2014) Product Category Rules for Insulation Materials (2014:13) version 1.0

European Commission (2013) Commission recommendation of 9 April 2013 on the use of common methods to measure and communicate the life cycle environmental performance of products and organizations (2013/179/EU). European Commission, Brussels

Fet AM, Skaar C (2006) Eco-labeling, Product Category Rules and certification procedures based on ISO 14025 requirements. Int J Life Cycle Assess 11:49-54. https://doi.org/10.1065/lca2006.01.237

Fries CE (2013) Avaliação do Impacto do uso de Tecnologias de Informação e Comunicação na Eficiência de Prestadores de Serviços Logísticos. Thesis, Universidade Federal de Santa Catarina

Galindro BM, Zanghelini GM, Soares SR (2019) Use of benchmarking techniques to improve communication in Life Cycle Assessment: a general review. J Clean Prod. 213:143-157. https://doi.org/10.1016/j.jclepro.2018.12.147

Gelowitz MDC, McArthur JJ (2017) Comparison of type III environmental product declarations for construction products: Material sourcing and harmonization evaluation. J Clean Prod 157:125-133. https://doi.org/10.1016/j.jclepro.2017.04.133

Gropp, W, Moré, JJ (1997) Optimization Environments and the NEOS Server. In: Approximation Theory and Optimization, M. D. Buhmann MD, Iserles, A (eds.). Cambridge University Press, p. 167-182.

Gül S, Spielmann M, Lehmann A, et al (2015) Benchmarking and environmental performance classes in life cycle assessment - development of a procedure for non-leather shoes in the context of the Product Environmental Footprint. Int J Life Cycle Assess 20:1640-1648. https://doi.org/10.1007/s11367-015-0975-7

Heijungs R, Henriksson PJG, Guinée JB (2017) Pre-calculated LCI systems with uncertainties cannot be used in comparative LCA. Int J Life Cycle Assess 22:461-461 https://doi.org/10.1007/s11367-017-1265-3

Henriksson PJG, Heijungs R, Dao HM, et al (2015) Product Carbon Footprints and their uncertainties in comparative decision contexts. PLoS One 10:1-11. https://doi.org/10.1371/journal.pone.012122

Hunsager EA, Bach M, Breuer L (2014) An institutional analysis of EPD programs and a global PCR registry. Int J Life Cycle Assess 19:786-795. https://doi.org/10.1007/s11367-014-0711-8

Ibáñez-Forés V, Pacheco-Blanco B, Capuz-Rizo SF, Bovea MD (2016) Environmental Product Declarations: exploring their evolution and the factors affecting their demand in Europe. J Clean Prod 116:157-169. https://doi.org/10.1016/j.jclepro.2015.12.078 
Ingwersen WW, Stevenson MJ (2012) Can we compare the environmental performance of this product to that one? An update on the development of product category rules and future challenges toward alignment. J Clean Prod 24:102-108. https://doi.org/10.1016/j.jclepro.2011.10.040

Iribarren D, Hospido A, Moreira MT, Feijoo G (2011) Benchmarking environmental and operational parameters through eco-efficiency criteria for dairy farms. Sci Total Environ 409:1786-1798. https://doi.org/10.1016/j.scitotenv.2011.02.013

Iribarren D, Martín-Gamboa M, Dufour J (2013) Environmental benchmarking of wind farms according to their operational performance. Energy 61:589-597. https://doi.org/10.1016/j.energy.2013.09.005

Iribarren D, Marvuglia A, Hild P, et al (2015) Life Cycle Assessment and Data Envelopment Analysis approach for the selection of building components according to their environmental impact efficiency: a case study for external walls. J Clean Prod 87:707-716. https://doi.org/10.1016/j.jclepro.2014.10.073

Iribarren D, Vázquez-Rowe I, Moreira MT, Feijoo G (2010) Further potentials in the joint implementation of Life Cycle Assessment and Data Envelopment Analysis. Sci Total Environ 408:5265-5272. https://doi.org/10.1016/j.scitotenv.2010.07.078

Iribarren D, Vázquez-Rowe I, Rugani B, Benetto E (2014) On the feasibility of using emergy analysis as a source of benchmarking criteria through data envelopment analysis: A case study for wind energy. Energy 67:527-537. https://doi.org/10.1016/j.energy.2014.01.109

ISO 14020:2000 (2000) International standard - Environmental labels and declarations - General principles. International Organization for Standardization. Geneva, Switzerland

ISO 14025:2006 (2006a) International standard - Environmental labels and declarations. Type III environmental declarations - principles and procedures. International Organization for Standardization. Geneva, Switzerland

ISO 14040:2006 (2006b) International standard - Environmental Management - Life Cycle Assessment - Principles and Framework. International Organization for Standardization. Geneva, Switzerland

ISO 14044:2006 (2006c) International standard - Environmental Management - Life Cycle Assessment Requirements and Guidelines. International Organization for Standardization. Geneva, Switzerland

Laso J, Vázquez-Rowe I, Margallo M, et al (2018) Revisiting the LCA+DEA method in fishing fleets. How should we be measuring efficiency? Mar Policy 91:34-40. https://doi.org/10.1016/j.marpol.2018.01.030

Li QJ, Wang KCP, Cross SA (2013) Evaluation of warm mix asphalt (WMA): A case study. 2013 Airfield and Highway Pavement Conference: Sustainable and Efficient Pavements. p. 118-127. https://doi.org/10.1061/9780784413005.011

Limleamthong P, Gonzalez-Miquel M, Papadokonstantakis S, et al (2016) Multi-criteria screening of chemicals considering thermodynamic and life cycle assessment metrics via data envelopment analysis: application to $\mathrm{CO}_{2}$ capture. Green Chem 18:6468-6481. https://doi.org/10.1039/C6GC01696K

Lorenzo-Toja Y, Vázquez-Rowe I, Amores MJ, et al (2016) Benchmarking wastewater treatment plants under an eco-efficiency perspective. Sci Total Environ 567:468-479. https://doi.org/10.1016/j.scitotenv.2016.05.110

Lorenzo-Toja Y, Vázquez-Rowe I, Chenel S, et al (2015) Eco-efficiency analysis of Spanish WWTPs using the LCA + DEA method. Water Res 8:651-666. https://doi.org/10.1016/j.watres.2014.10.040

Lorenzo-Toja Y, Vázquez-Rowe I, Marín-Navarro D, et al (2018). Dynamic environmental efficiency assessment for wastewater treatment plants. Int J Life Cycle Assess 23(2):357-367. 
Lozano S, Iribarren D, Moreira MT, Feijoo G (2009) The link between operational efficiency and environmental impacts: a joint application of Life Cycle Assessment and Data Envelopment Analysis. Sci Total Environ 407:17441754. https://doi.org/10.1016/j.scitotenv.2008.10.062

Lozano S, Iribarren D, Moreira MT, Feijoo G (2010) Environmental impact efficiency in mussel cultivation. Resour Conserv Recycl 54:1269-1277. https://doi.org/10.1016/j.resconrec.2010.04.004

Martín-Gamboa M, Iribarren D (2016). Dynamic Ecocentric Assessment combining Emergy and Data Envelopment Analysis: application to wind farms. Resources 5:8. https://doi.org/10.3390/resources5010008

Martín-Gamboa M, Iribarren D, Susmozas A, Dufour J (2016) Delving into sensible measures to enhance the environmental performance of biohydrogen: a quantitative approach based on process simulation, Life Cycle Assessment and Data Envelopment Analysis. Bioresour Technol 214:376-385. https://doi.org/10.1016/j.biortech.2016.04.133

Minkov N, Schneider L, Lehmann A, Finkbeiner M (2015) Type III Environmental Declaration Programmes and harmonization of product category rules: Status quo and practical challenges. J Clean Prod 94:236-246. https://doi.org/10.1016/j.jclepro.2015.02.012

Modahl IS, Askham C, Lyng KA, et al (2013) Comparison of two versions of an EPD, using generic and specific data for the foreground system, and some methodological implications. Int J Life Cycle Assess 18:241-251. https://doi.org/10.1007/s11367-012-0449-0

Mohammadi A, Rafiee S, Jafar, A, et al (2013) Potential greenhouse gas emission reductions in soybean farming: A combined use of Life Cycle Assessment and Data Envelopment Analysis. J Clean Prod 54:89-100. https://doi.org/10.1016/j.jclepro.2013.05.019

Mohammadi A, Rafiee S, Jafari A, et al (2015) Joint Life Cycle Assessment and Data Envelopment Analysis for the benchmarking of environmental impacts in rice paddy production. J Clean Prod 106:521-532. https://doi.org/10.1016/j.jclepro.2014.05.008

Oers, L. van, 2015. CML-IA database, characterization and normalization factors for midpoint impact category indicators. Version 4.5, April 2015. Available at: http://clm.leiden.edu/software/data-cmlia.html

Paradi JC, Sherman HD, Tam FK (2018) DEA Models Overview. In: Data Envelopment Analysis in the Financial Services Industry. International Series in Operations Research \& Management Science, vol 266. Springer, Cham

Ramos S, Vázquez-Rowe I, Artetxe I, et al (2014) Operational efficiency and environmental impact fluctuations of the basque trawling fleet using LCA+DEA methodology. Turkish J Fish Aquat Sci 14:77-70. https://doi.org/10.4194/1303-2712-v14_1_10

Seiford LM, Zhu J (2002) Modeling undesirable factors in efficiency evaluation. Eur J Oper Res 142:16-20. https://doi.org/10.1016/S0377-2217(01)00293-4

Vázquez-Rowe I, Iribarren D (2015) Review of life-cycle approaches coupled with data envelopment analysis: Launching the CFP + DEA method for energy policy making. Sci World J 2015. https://doi.org/10.1155/2015/813921

Vázquez-Rowe I, Iribarren D, Hospido A, et al (2011) Computation of operational and environmental benchmarks within selected galician fishing fleets. J Ind Ecol 15:776-795.

Vázquez-Rowe I, Iribarren D, Moreira MT, Feijoo G (2010) Combined application of Life Cycle Assessment and Data Envelopment Analysis as a methodological approach for the assessment of fisheries. Int J Life Cycle Assess 15:272-283. https://doi.org/10.1007/s11367-010-0154-9 
604 Vázquez-Rowe I, Villanueva-Rey P, Iribarren D, et al (2012) Joint life cycle assessment and data envelopment 605 analysis of grape production for vinification in the Rías Baixas appellation (NW Spain). J Clean Prod 27:92-102. 606 https://doi.org/10.1016/j.jclepro.2011.12.039

607 Zhu J (2015) Data envelopment analysis. A handbook of models and methods. 1st ed. Springer. 